\title{
KARAKTERISTIK COKELAT FILLING KACANG METE YANG DIPENGARUHI JENIS DAN JUMLAH LEMAK NABATI
}

\author{
Asep Dedy Sutrisno \\ Yusep Ikrawan \\ Nurul Permatasari \\ Program Studi Teknologi Pangan, Fakultas Teknik, Universitas Pasundan, Jl. Dr.Setiabudi No 93, Bandung, 40153, \\ Indonesia \\ E-mail : asepdedysutrisno@unpas.ac.id
}

\begin{abstract}
Abstrak
Tujuan dari penelitian ini adalah untuk mempelajari dan mengetahui karakteristik cokelat filling kacang mete (Anacardium occidentale L.) yang dipengaruhi jenis dan jumlah lemak nabati. Penelitian ini diharapkan dapat memberikan informasi mengenai pengaruh penggunaan jenis lemak nabati dan jumlah lemak nabati dalam pembuatan cokelat filling kacang mete (Anacardium occidentale L.). Diharapkan dapat memberikan informasi pengembangan teknologi, pengolahan dan wawasan yang luas dalam membuat produk cokelat filling kacang mete (Anacardium occidentale L.), serta memberikan informasi mengenai pengaruh proses pengolahan terhadap neraca bahan komponen lemak. Rancangan percobaan yang digunakan dalam penelitian ini adalah pola faktorial 3 x 3 dalam Rancangan Acak Kelompok (RAK) dan ulangan yang dilakukan sebanyak tiga kali. Pola percobaan faktorial tersebut terdiri dari dua faktor, yaitu : faktor A (jenis lemak nabati) terdiri dari 3 taraf yaitu : cocoa butter (a1), vegetable shortening (a2) dan margarin (a3) dan faktor B (jumlah lemak nabati) terdiri dari 3 taraf yaitu: 25\% (b1), 20\% (b2) dan 15\% (b3). Hasil analisis dan perhitungan statistik pada penelitian utama menunjukkan faktor A (jenis lemak nabati) berpengaruh terhadap kadar lemak, titik leleh, tekstur, titik beku, rasa, dan aroma. Faktor B (jumlah lemak nabati) berpengaruh terhadap kadar lemak, titik leleh, dan tekstur. Interaksi antara faktor A (jenis lemak nabati) dan B (jumlah lemak nabati) berpengaruh terhadap titik leleh.
\end{abstract}

\section{Abstract}

The purpose of this research was to learn and know characteristic chocolate filling cashew nut (Anacardium occidentale L.) influenced by the type and amount of vegetable fat. This research was expected to provide information about the effect of the type and amount of vegetable fat in the manufacture of chocolate filling cashew nut (Anacardium occidentale L.). Expected to provide information about technology development, processing and extensive knowledge in the manufacture of chocolate filling cashew nut (Anacardium occidentale L.), and provide information about the effect of processing on fat component material. Experimental design used in this research was 3 x 3 factorial pattern in randomized block design (RAK) and with three replications. The pattern of factorial experiment consisted of two factors: A factor (type of vegetable fat) consists of 3 level were: cocoa butter (a1), vegetable shortening (a2) and margarine (a3) and B factor (amount of vegetable fat) consists of 3 level were: 25\% (b1), 20\% (b2) and 15\% (b3). The result of statistical analysis in primary research shows that the A factor (type of vegetable fat) take effect to fat content, melting point, texture, freezing point, taste and aroma. B factor (amount of vegetable fat) take effect to fat content, melting point and texture. interaction between A factor (type of vegetable fat) with B factor (amount of vegetable fat) take effect to melting point.

Keywords: Chocolate, vegetable fat.

\section{Pendahuluan}

Kakao telah dikenal di Indonesia sejak tahun 1560 tetapi baru menjadi komoditi yang penting sejak tahun 1951. Produksi kakao Indonesia dihasilkan dari perkebunan besar Negara dan swasta yang terdapat di daerah Sumatera Utara dan Jawa Timur, selain itu juga produksi yang berasal dari perkebunan rakyat yang tersebar di daerah-daerah Maluku, Sulawesi Selatan, Kalimantan Timur, dan Irian Jaya. Meningkatnya usaha di bidang pembudidayaan kakao ini telah dapat meningkatkan hasil devisa bagi Negara melalui ekspor dan mendorong ekonomi daerah terutama daerah pedesaan. Untuk itu sejak tahun 1980 Pemerintah memberikan prioritas terhadap produksi kakao sebagai salah satu mata dagangan yang dikembangkan secara tepat (Siregar, Slamet dan Laeli, 2000).

Produksi kakao Indonesia setiap tahun selalu mengalami peningkatan, menurut data statistik sejak tahun 1987 hingga tahun 1992 rata-rata peningkatan yang terjadi berkisar 25,63\% per tahun.

Pada awal abad ke-19 ditemukan cara memisahkan dan mengambil kandungan lemak dari biji kakao, sehingga diperoleh cocoa butter, bahan cocoa powder, dan hasil pengolahan biji-biji kakao. Kemudian disusul dengan pembuatan manisan dari kakao yaitu 
kembang gula. Konon, pembuatan milk chocolate baru dimulai pada tahun 1876 di Negara Swiss (Sunanto, 1992).

Produk cokelat cukup beraneka ragam, misalnya ada cokelat susu yang merupakan adonan cokelat manis, cocoa butter, gula, dan susu. Selain itu ada pula cokelat pahit (dark chocolate) yang merupakan cokelat alami dan mengandung sekitar $43 \%$ padatan cokelat. Cokelat jenis ini bisa ditemukan pada beberapa produk cokelat batangan (Khomsan, 2004).

Konsumsi kakao Indonesia dalam bentuk olahan dibedakan menjadi konsumsi cokelat instan dan cocoa powder. Berdasarkan hasil SUSENAS dari Badan Pusat Statistik, perkembangan konsumsi kakao tahun 2002-2013 cukup berfluktuasi. Konsumsi cokelat instan di Indonesia selama periode tersebut meningkat sebesar $24,89 \%$ per tahun. Lonjakan konsumsi yang sangat signifikan terjadi pada tahun 2012, dimana konsumsi cokelat instan mencapai 54,6 gram/kapita atau naik 133,33\% dibandingkan tahun sebelumnya (Pusat Data Sistem Informasi Pertanian, 2014).

Konsumsi masyarakat terhadap cokelat semakin meningkat, hal ini karena rasa khas cokelat yang sangat lezat dan menarik, terlebih bila cokelat tersebut ditambahkan dengan bahan pengisi (filling) sebagai pelengkap. Tetapi daya beli masyarakat terhadap cokelat olahan sebagian besar hanya bisa dijangkau oleh kalangan menegah ke atas, karena cokelat dengan mutu baik sebagian didatangkan dari luar negeri sehingga harga yang ditawarkan pun sangat tinggi dan tidak dapat terjangkau oleh seluruh lapisan masyarakat.

Harga cokelat yang cukup tinggi ini dikarenakan digunakannya lemak yaitu cocoa butter sebagai bahan utama, cocoa butter atau lemak kakao dalam pembuatan cokelat termasuk lemak nabati yang memiliki kandungan lemak tinggi.

Pengganti cocoa butter walaupun memiliki tingkat ketahanan berbeda dengan cocoa butter akan tetapi dapat menghasilkan cokelat dengan kualitas baik tentunya dengan harga terjangkau dibandingkan cocoa butter (Saleh, 2005).

Pengganti cocoa butter untuk pembuatan cokelat diantaranya adalah lemak nabati yang memiliki titik leleh cukup tinggi (tidak cair di suhu ruang), seperti vegetable shortening dan margarin.

Vegetable shortening adalah lemak padat yang mempunyai sifat plastis dan kestabilan tertentu dan umumnya berwarna putih. Pada umumnya vegetable shortening dibuat dari minyak nabati seperti minyak biji kapas, minyak kacang kedelai, minyak kacang tanah, dan lain-lain (Winarno,1991).

Margarin adalah emulsi air dalam minyak (W/O) yang mana tersebar dalam fase lemak semi-padat mengandung kristal-kristal lemak dan minyak cair. Margarin dimaksudkan sebagai pengganti mentega karena memiliki rupa, bau, konsistensi rasa dan nilai gizi yang hampir sama dengan mentega (Ketaren, 1986).

Jenis lemak nabati yang digunakan dalam pembuatan cokelat memiliki sifat yang berbeda-beda sehingga karakteristik produk cokelat yang dihasilkan akan berbeda pula antara satu dan lainnya, baik secara organoleptik, fisika, maupun kimia.

Cita rasa cokelat akan lebih khas bila ditambahkan bahan pengisi, jenis bahan pengisi yang dapat ditambahkan adalah kacang-kacangan atau buahbuahan segar (Moeljianingsih, 2011). Kacang mete memiliki kandungan lemak yang tinggi yaitu sekitar $47 \%$ dan memiliki kandungan air $\pm 5 \%$, dengan kandungan lemaknya yang cukup tinggi maka akan menambah cita rasa dari produk akhir cokelat. Kemudian kacang-kacangan memiliki kandungan air yang lebih sedikit dibandingkan dengan buah-buahan sehingga tidak akan mempengaruhi emulsi dalam adonan cokelat (Astawan, 2009).

Lemak merupakan fase utama dari cokelat, sehingga komponen lemak dalam produk cokelat adalah penting untuk diketahui. Komponen lemak dalam produk akhir dipengaruhi oleh bahan baku yang digunakan, kemudian karena adanya proses pengolahan akan mengakibatkan perubahan komponen lemak baik meningkat maupun menurun.

Di suatu industri pangan adalah penting untuk mengetahui pengaruh proses pengolahan terhadap komponen kimia (lemak) dan penyusutan jumlah bahan (lost) sehingga diperlukan kajian mengenai hal tersebut, salah satu cara yang dapat digunakan adalah dengan perhitungan neraca bahan komponen lemak.

\section{Metode Penelitian}

Bahan-bahan yang akan digunakan dalam penelitian ini adalah vegetable shortening merek Pusaka, cocoa powder bensdoorp, gula tepung, kacang mete yang diperoleh dari toko bahan kue sejati, cocoa butter, margarin filma unsalted, cocoa butter substitute yang diperoleh dari toko bahan kue $\mathrm{Ny}$. Liem dan lesitin kedelai dari toko brataco chemical.

Bahan analisis kimia yang digunakan dalam penelitian ini adalah aquades dan pelarut (N-Heksan).

Alat-alat yang akan digunakan dalam penelitian ini adalah timbangan digital, panci, kompor gas, alat pengaduk, mixer, concher, water bath, wadah plastik, sendok, cetakan cokelat, alumunium foil, dan lemari pendingin.

Alat-alat yang digunakan dalam analisa kimia dan fisika adalah penetrometer, timbangan digital, kertas saring, alat ekstraksi soxhlet lengkap dengan kondensor dan labu lemak, oven, desikator, penjepit cawan, pipet, botol semprot, erlenmeyer, batang statif, seperangkat alat pemanas, pipa kapiler, gelas kimia, dan termometer.

Metode penelitian yang dilakukan terdiri dari dua tahap, yaitu penelitian pendahuluan yang bertujuan untuk menganalisis kadar lemak dari setiap bahan baku, 
data hasil analisis digunakan untuk perhitungan neraca bahan komponen lemak. Penelitian pendahuluan juga dilakukan untuk mempersempit rentang jumlah lemak nabati yang digunakan dalam penelitian utama. Jumlah lemak nabati yang digunakan dalam penelitian pendahuluan I (cocoa butter) yaitu 25\%;30\%;35\%, untuk penelitian pendahuluan II (vegetable shortening) $15 \% ; 20 \% ; 25 \%$ dan untuk penelitian pendahuluan III (margarin) $5 \% ; 10 \% ; 15 \%$, dari setiap penelitian pendahuluan akan didapatkan satu jumlah lemak nabati terpilih berdasarkan uji organoleptik.

Penelitian utama bertujuan untuk mengetahui karakteristik cokelat filling kacang mete yang dipengaruhi jenis dan jumlah lemak nabati, selanjutnya dilakukan rancangan perlakuan, rancangan percobaan, rancangan analisis, dan rancangan respon.

Penelitian utama dilakukan dengan menggunakan rancangan perlakuan yang terdiri dari dua faktor yaitu jenis lemak nabati (A) yang terdiri dari 3 taraf yaitu cocoa butter, vegetable shortening, margarin dan jumlah lemak nabati (B) yang terdiri dari 3 taraf yaitu jumlah lemak terpilih dari penelitian pendahuluan I, II, III. Kemudian rancangan percobaan menggunakan Rancangan Acak Kelompok (RAK) dengan 3 kali ulangan (Gaspersz, 1990), rancangan analisis dengan analisis variansi (ANAVA) dan rancangan respon kimia (kadar lemak), respon fisika (titik leleh, tekstur, titik beku), respon organoleptik metode uji hedonik (Kartika, B, 1987)

\section{Hasil dan Pembahasan}

\section{Hasil Penelitian Pendahuluan}

\section{Analisis Kadar Lemak Sampel}

Analisis kimia yang dilakukan di pendahuluan adalah analisis kadar lemak terhadap seluruh bahan baku yang digunakan yaitu cocoa powder, cocoa butter, vegetable shortening, margarin, cocoa butter substitute, gula tepung, lesitin dan kacang mete. Hasil dari analsis kimia ini akan digunakan dalam perhitungan neraca bahan komponen lemak di penelitian utama.

Tabel 1. Hasil Analisis Bahan Baku

\begin{tabular}{|l|l|}
\hline Bahan (Sampel) & $\begin{array}{l}\text { Kadar } \\
\text { Lemak }(\%)\end{array}$ \\
\hline Cocoa butter & 88.82 \\
\hline Vegetable Shortening & 88.76 \\
\hline Margarin & 77.89 \\
\hline Cocoa Powder & 22.2 \\
\hline Gula Tepung & 0.00 \\
\hline Cocoa Butter Substitute & 73.85 \\
\hline Lesitin & 70.55 \\
\hline Kacang Mete & 60.20 \\
\hline
\end{tabular}

\section{Uji Organoleptik}

Uji organoleptik di penelitian pendahuluan ini dilakukan untuk mendapatkan tiga jumlah lemak nabati yang digunakan di penelitian utama, uji organoleptik ini dilakukan dengan menggunakan metode hedonik, sehingga dapat diketahui apakah jumlah lemak yang akan di gunakan tersebut disukai atau tidak oleh panelis.

Parameter yang digunakan dalam penelitian pendahuluan ini adalah rasa, tekstur (mouth feel), aroma dan after taste (pahit). Pengujian dilakukan dengan melibatkan 20 orang panelis.

\section{a. Respon Organoleptik Pendahuluan I}

Bahan yang digunakan dalam pembuatan produk untuk uji organoleptik pendahuluan I ini adalah cocoa butter dengan tiga jumlah variasi yaitu $35 \%$, 30\%, dan $25 \%$.

Tabel 2. Hasil Uji Organoleptik Pendahuluan I

\begin{tabular}{|c|c|c|c|c|c|c|c|}
\hline Kode & Jumlah & \multicolumn{5}{|c|}{ Nilai Rata-Rata } & \multirow{2}{*}{ Jumlah } \\
\cline { 3 - 7 } Sampel & Lemak & Rasa & \multicolumn{2}{|c|}{ Tekstur } & Aroma & After taste & \\
\hline 178 & $35 \%$ & 2.29 a & 2.21 & a & 2.24 a & 2.31 a & 9.06 \\
\hline 183 & $30 \%$ & 2.20 a & 2.30 & a & 2.26 a & 2.17 a & 8.92 \\
\hline 102 & $25 \%$ & 2.36 a & 2.18 & a & $\mathbf{2 . 2 3}$ a & 2.30 a & 9.07 \\
\hline
\end{tabular}

Berdasarkan hasil pengolahan data yang telah dilakukan diketahui bahwa dari penggunaan ketiga variasi jumlah lemak adalah tidak berbeda nyata untuk semua atribut yaitu rasa, tekstur, aroma dan after taste. Maka jumlah lemak terpilih ditentukan dengan melihat nilai rata-rata yang menyatakan tingkat kesukaan panelis, yaitu $25 \%$.

Panelis lebih menyukai produk cokelat dengan jumlah lemak $25 \%$, rasa dari produk cokelat lebih disukai karena rasa khas cokelat lebih terasa. Hal ini dikarenakan pada formulasi jumlah lemak 25\%, penggunaan cocoa powder lebih banyak daripada formulasi lain yaitu $30 \%$.

\section{b. Respon Organoleptik Pendahuluan II}

Bahan yang digunakan dalam pembuatan produk untuk uji organoleptik pendahuluan II ini adalah vegetable shortening dengan tiga jumlah variasi yaitu $25 \%, 20 \%$, dan $15 \%$.

Berdasarkan hasil pengolahan data anava yang telah dilakukan diketahui bahwa dari penggunaan ketiga variasi jumlah lemak adalah tidak berbeda nyata untuk atribut tekstur (mouth feel), aroma dan after taste (pahit), untuk atribut rasa berdasarkan tabel anava adalah berbeda nyata sehingga dilakukan uji lanjut duncan. Jumlah lemak yang terpilih adalah $20 \%$, hal ini karena penggunaan lemak $20 \%$ memiliki nilai yang paling banyak disukai panelis dalam hal atribut rasa, tekstur dan after taste.

Tabel 3. Hasil Uji Organoleptik Pendahuluan II

\begin{tabular}{|c|c|cc|cc|cc|cc|c|}
\hline Kode & Jumlah & \multicolumn{7}{|c|}{ Nilai Rata-Rata } & \multirow{2}{*}{ Jumlah } \\
\cline { 3 - 9 } Sampel & Lemak & \multicolumn{2}{|c|}{ Rasa } & \multicolumn{2}{|c|}{ Tekstur } & Aroma & \multicolumn{2}{|c|}{ After taste } & \\
\hline 246 & $25 \%$ & 2.06 & a & 2.19 & a & 2.22 & a & 2.03 & ab & 8.50 \\
\hline $\mathbf{2 7 5}$ & $\mathbf{2 0} \%$ & $\mathbf{2 . 2 5}$ & b & $\mathbf{2 . 2 2}$ & a & $\mathbf{2 . 1 5}$ & a & $\mathbf{2 . 1 5}$ & B & $\mathbf{8 . 7 7}$ \\
\hline 208 & $15 \%$ & 2.14 & ab & 2.18 & a & 2.20 & a & 1.91 & A & 8.43 \\
\hline
\end{tabular}

Rasa, tekstur dan after taste dari produk cokelat dengan menggunakan vegetable shortening $20 \%$ lebih disukai, hal ini dikarenakan formulasi keseluruhan yang digunakan. Tekstur menjadi lembut dan tidak berpasir karena persentase penggunaa bahan padat (serbuk) seimbang, hal ini pula yang menyebabkan panelis 
menyukai produk cokelat dari segi rasa dan after taste (pahit).

\section{c. Respon Organoleptik Pendahuluan III}

Bahan yang digunakan dalam pembuatan produk untuk uji organoleptik pendahuluan III ini adalah margarin dengan tiga variasi yaitu 15\%, 10\%, 5\%.

Tabel 4. Hasil Uji Organoleptik Pendahuluan III

\begin{tabular}{|c|c|cc|cc|cc|cc|c|}
\hline Kode & Jumlah & \multicolumn{7}{|c|}{ Nilai Rata-Rata } & \multirow{2}{*}{ Jumlah } \\
\cline { 3 - 10 } Sampel & Lemak & \multicolumn{2}{|c|}{ Rasa } & \multicolumn{2}{|c|}{ Tekstur } & \multicolumn{2}{|c|}{ Aroma } & After taste & \\
\hline 304 & $15 \%$ & 2.00 & c & 2.24 & b & 2.11 & b & 2.00 & b & 8.36 \\
\hline 379 & $10 \%$ & 1.82 & b & 2.17 & ab & 2.13 & b & 1.89 & b & 8.01 \\
\hline 336 & $5 \%$ & 1.71 & a & 2.13 & a & 2.01 & a & 1.75 & a & 7.59 \\
\hline
\end{tabular}

Menurut uji lanjut Duncan hasil uji organoleptik dengan metode hedonik terhadap rasa, tekstur (mouth feel), aroma dan after taste (pahit) pada penelitian pendahuluan III terpilih jumlah lemak $15 \%$, hal ini karena pada atribut rasa, tekstur dan after taste produk mempunyai nilai yang paling disukai panelis. Lebih disukainya perlakuan dengan jumlah $15 \%$ oleh panelis ini dikarenakan formulasi keseluruhan yang digunakan. Pada formulasi jumlah lemak $15 \%$ after taste dari produk cokelat tidak terlalu pahit dibandingkan dengan formulasi lainnya, hal ini juga yang mempengaruhi penerimaan panelis terhadap rasa keseluruhan dari produk, kemudian tekstur dari produk cokelat tidak terlalu padat dibandingkan dengan formulasi lainnya sehingga tekstur (mouth feel) lebih disukai.

\section{Hasil Penelitian Utama}

\section{Kadar Lemak}

Lemak dan minyak terdapat pada hampir semua bahan dengan kandungan yang berbeda-beda, tetapi lemak dan minyak sering kali ditambahkan dengan sengaja ke dalam bahan makanan dengan berbagai tujuan. Penambahan lemak dimaksudkan untuk menambah kalori serta memperbaiki tekstur dan cita rasa bahan pangan, seperti pada kembang gula. Penambahan lemak dapat meningkatkan cita rasa dan mutu dari suatu makanan, namun penggunaannya harus tetap terkendali dan jumlahnya tidak berlebihan (Winarno, 1991).

Tabel 5. Pengaruh Jenis Lemak Nabati (A) terhadap Kadar Lemak Cokelat

\begin{tabular}{|l|l|l|}
\hline Jenis Lemak & $\begin{array}{l}\text { Rata-Rata } \\
\text { (\% Lemak) }\end{array}$ & $\begin{array}{l}\text { Taraf } \\
\text { Nyata } \\
5 \%\end{array}$ \\
\hline $\begin{array}{l}\text { a1 } \\
\text { (Cocoa Butter })\end{array}$ & 34.18 & $\mathrm{~B}$ \\
\hline $\begin{array}{l}\text { a2 } \\
\text { (Vegetable } \\
\text { Shortening) }\end{array}$ & 33.68 & $\mathrm{~b}$ \\
\hline $\begin{array}{l}\text { a3 } \\
\text { (Margarin) }\end{array}$ & 31.60 & $\mathrm{a}$ \\
\hline
\end{tabular}

Berdasarkan hasil analisis kadar lemak cokelat untuk setiap perlakuan serta hasil sidik ragam (ANAVA), menunjukkan bahwa interaksi antara jenis lemak nabati (A) dan jumlah lemak nabati (B) tidak berpengaruh nyata terhadap kadar lemak produk cokelat. Berbeda dengan jenis lemak nabati (A) dan jumlah lemak nabati (B) yang secara mandiri memberikan pengaruh nyata terhadap kadar lemak produk cokelat.

Tabel 6. Pengaruh Jumlah Lemak Nabati (B) terhadap Kadar Lemak Cokelat

\begin{tabular}{|l|l|l|}
\hline $\begin{array}{c}\text { Jumlah } \\
\text { Lemak }\end{array}$ & $\begin{array}{c}\text { Rata-Rata } \\
(\% \text { Lemak) }\end{array}$ & $\begin{array}{c}\text { Taraf } \\
\text { Nyata 5\% }\end{array}$ \\
\hline b1 $(25 \%)$ & 35.33 & c \\
\hline b2 $(20 \%)$ & 33.43 & b \\
\hline b3 $(15 \%)$ & 30.71 & a \\
\hline
\end{tabular}

Kadar lemak dalam produk cokelat dengan penambahan cocoa butter dan vegetable shortening sebagai sumber lemak tidak berbeda nyata, hal ini dikarenakan kadar lemak dari cocoa butter dan vegetable shortening yang digunakan tidak memiliki perbedaan yang besar pula yaitu $88.82 \%$ dan $88.76 \%$. Sementara kadar lemak produk cokelat dengan penambahan margarin memiliki perbedaan yang nyata, hal ini dikarenakan kadar lemak margarin sebagai bahan baku relatif lebih rendah bila dibandingkan dengan dua jenis lemak lainnya, yaitu $77.89 \%$.

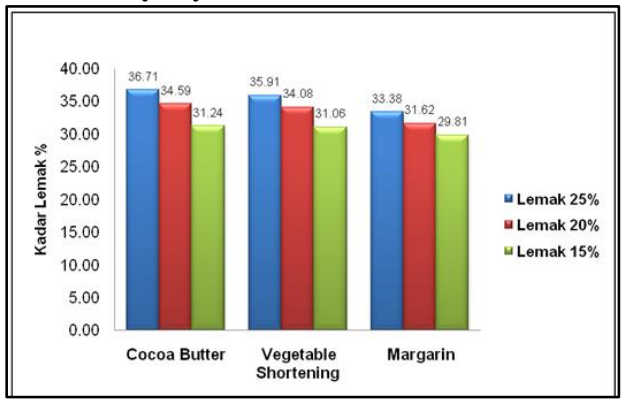

Gambar 1. Histogram Hubungan antara Jenis Lemak Nabati dan Jumlah Lemak Nabati Terhadap Kadar Lemak Cokelat

Berdasarkan histogram diatas, menunjukkan bahwa dengan semakin meningkatnya jumlah lemak yang digunakan maka kadar lemak produk cokelat juga akan meningkat.

Semakin meningkatnya kadar lemak dipengaruhi oleh semakin tingginya jumlah lemak yang digunakan, selain itu penggunaan bahan lainnya yang memiliki kadar lemak cukup besar seperti cocoa powder (22.2\%) dan kacang mete $(60.2 \%)$ memberikan pengaruh yang cukup besar pula terhadap kadar lemak produk. Kebanyakan konsumen menginginkan produk cokelat dengan kadar lemak yang rendah, sehingga jika ingin memperoleh produk cokelat dengan kadar lemak yang rendah dapat menggunakan formulasi pada perlakuan a3b3 (margarin 15\%), a2b3 (vegetable shortening 15\%), dan alb3 (cocoa butter 15\%).

Kacang mete yang ditambahkan memberikan pengaruh yang cukup besar terhadap kadar lemak dari cokelat, terlebih bila cokelat tersebut mengalami penyimpanan. Selama penyimpanan, dapat 
dimungkinkan terjadinya fat migration minyak / lemak yang terdapat dalam kacang mete terhadap cokelat sehingga kadar lemak cokelat menjadi berubah.

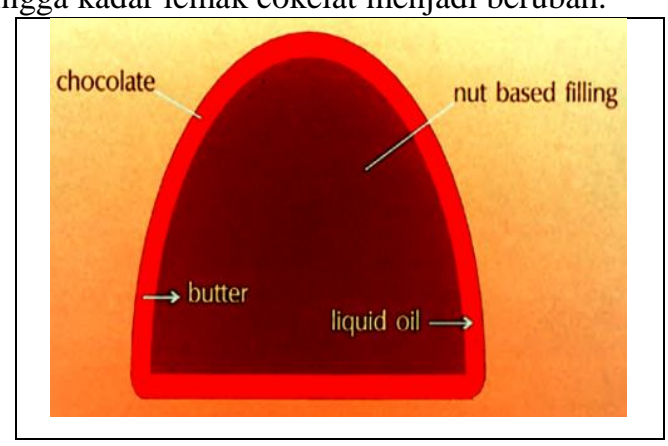

Gambar 2. Ilustrasi Fat Migration

Fat migration dapat menjadi penyebab terjadinya gejala fat blooming seperti timbulnya bintik-bintik putih di permukaan cokelat, kenampakan menjadi kusam dan tidak mengkilap serta tekstur (hand feel) yang berpasir. Blooming terjadi apabila kristal lemak yang stabil berubah menjadi tidak stabil. Perubahan ini mengakibatkan adanya ruang kosong antar kristal lemak sehingga terbentuk pipa kapiler, hal ini menyebabkan kenampakan cokelat berubah menjadi kurang menarik, lemak yang bermigrasi juga menggunakan pipa kapiler yang terbentuk untuk dapat naik ke permukaan (Fakhmi, 2016).

\section{Neraca Bahan Komponen Lemak}

Perolehan kadar lemak produk cokelat dilakukan dengan perhitungan neraca bahan komponen lemak, dimana data yang dibutuhkan untuk perhitungan didapatkan dari analisis kimia di penelitian pendahuluan serta persentase bahan dari setiap formulasi. Berikut adalah perbandingan antara kadar lemak yang dihitung berdasarkan neraca bahan komponen lemak dan berdasarkan analisis metode soxhlet.

Tabel 7. Hasil Perhitungan Neraca Bahan Komponen Lemak (\%)

\begin{tabular}{|l|l|l|}
\hline \multirow{2}{*}{ Perlakuan } & \multicolumn{2}{|c|}{ Lemak (\%) } \\
\cline { 2 - 3 } & $\begin{array}{c}\text { Perhitungan } \\
\text { Neraca } \\
\text { Bahan }\end{array}$ & $\begin{array}{c}\text { Analisis } \\
\text { Metode } \\
\text { Soxhlet }\end{array}$ \\
\hline a1b1 & 39.91 & 36.71 \\
\hline a1b2 & 36.47 & 34.59 \\
\hline a1b3 & 33.01 & 31.24 \\
\hline a2b1 & 39.80 & 35.91 \\
\hline a2b2 & 36.47 & 34.08 \\
\hline a2b3 & 33.06 & 31.06 \\
\hline a3b1 & 36.90 & 33.38 \\
\hline a3b2 & 34.18 & 31.62 \\
\hline a3b3 & 31.46 & 29.81 \\
\hline
\end{tabular}

Berdasarkan tabel diatas dapat diketahui bahwa kadar lemak setiap perlakuan yang di analisis menggunakan metode soxhlet lebih rendah dari kadar lemak yang diperoleh dengan cara perhitungan neraca bahan komponen. Hal ini dikarenakan selama pemanasan, lemak akan mengalami degradasi menjadi asam lemak sehingga produk degradasi terbagi menjadi dua yaitu hasil degradasi tidak menguap yang tetap terdapat dalam bahan dan hasil degradasi yang dapat menguap yang keluar bersama-sama dengan uap pada waktu lemak dipanaskan. Pemanasan berkelanjutan menyebabkan kadar lemak menurun, semakin tinggi suhu yang digunakan, maka kerusakan lemak akan semakin meningkat (Muchtadi, 1989).

Pemanasan yang dilakukan dalam pembuatan cokelat akan menyebabkan pecahnya komponenkomponen lemak menjadi produk volatil seperti aldehid, keton, alkohol, asam, dan hidrokarbon yang sangat mudah menguap dan berpengaruh terhadap pembentukan flavor (Zogina, 2015).

\section{Titik Leleh}

Titik leleh dari cokelat merupakan parameter yang penting dalam menentukan kualitas dari prosuk cokelat, cokelat yang baik tidak cepat meleleh di suhu ruang namun dapat cepat meleleh di suhu tubuh.

Hasil penelitian bervariansi dari setiap perlakuan untuk titik leleh cokelat. Dari hasil analisis titik leleh cokelat untuk setiap perlakuan serta hasil sidik ragam (ANAVA), menunjukkan bahwa interaksi antara jenis lemak nabati (A) dan jumlah lemak nabati (B) berpengaruh nyata terhadap titik leleh cokelat.

Tabel 8. Pengaruh Jenis Lemak Nabati dan Jumlah Lemak Nabati terhadap Titik Leleh Cokelat

\begin{tabular}{|l|l|l|l|}
\hline Faktor & \multicolumn{3}{|l|}{ Jumlah Lemak Nabati (B) } \\
\hline $\begin{array}{l}\text { Jenis } \\
\text { Lemak }\end{array}$ & $\begin{array}{l}\text { babati } \\
(25 \%)\end{array}$ & $\begin{array}{l}\text { b2 } \\
(20 \%)\end{array}$ & $\begin{array}{l}\text { b3 } \\
(15 \%)\end{array}$ \\
\hline $\begin{array}{l}\text { a1 } \\
\text { (cocoa }\end{array}$ & 29.89 & 33.67 & 35.22 \\
butter) & $\mathrm{a}$ & $\mathrm{B}$ & $\mathrm{c}$ \\
\hline $\begin{array}{l}\text { a2 } \\
\text { (vegetable }\end{array}$ & AB & B & A \\
shortening) & a & 32.44 & 34.22 \\
\hline a3 & A & A & c \\
(margarin) & 29.11 & 31.44 & A \\
\hline
\end{tabular}

Keterangan :

1.Huruf (kecil) dibaca horizontal, huruf yang berbeda menyatakan perbedaan yang nyata pada taraf $5 \%$.

2. Huruf (besar) dibaca vertikal, huruf yang berbeda menyatakan perbedaan yang nyata pada taraf $5 \%$.

Berdasarkan tabel 8, perlakuan jumlah lemak nabati (B) yaitu pada b1, b2 dan b3 menunjukkan perbedaan yang nyata terhadap titik leleh pada seluruh perlakuan jenis lemak nabati (A) baik pada a1, a2 maupun a3.

Perlakuan a1b1 menunjukan perbedaan yang nyata terhadap titik leleh pada perlakuan a1b3 namun tidak berbeda nyata dengan perlakuan a1b2, kemudian perlakuan a1b2 tidak menunjukan perbedaan yang nyata dengan a1b3. 
Perlakuan a2b1 menunjukan perbedaan yang nyata terhadap perlakuan a2b3 dan a2b2. Selanjutnya perlakuan a3b1 menunjukan perbedaan yang nyata terhadap titik leleh a2b3, namun perlakuan a2b3 dan a3b3 tidak menunjukan perbedaan yang nyata terhadap a3b3.

Perbedaan titik leleh antar produk cokelat setiap formulasi dikarenakan kandungan asam lemak yang berbeda. Asam lemak yang menyusun suatu bahan memiliki karakteristik yang berbeda-beda. Titik leleh lemak sangat ditentukan oleh komposisi asam lemak dan tipe tri-acyl glycerol (Misnawi, 2008).

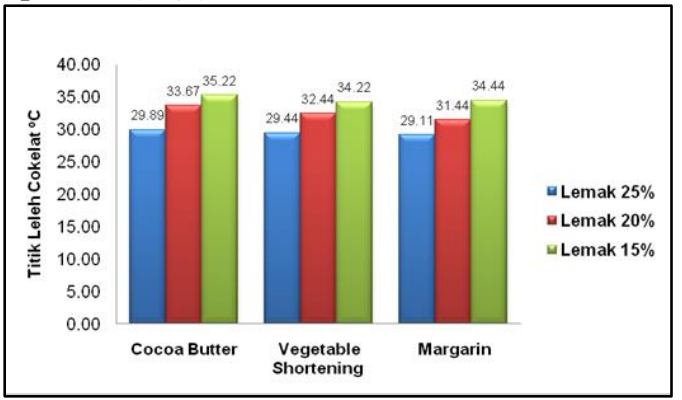

Gambar 3. Histogram Hubungan antara Jenis Lemak Nabati dan Jumlah Lemak Nabati Terhadap Titik Leleh Cokelat

Berdasarkan histogram, menunjukkan bahwa dengan semakin meningkatnya jumlah lemak yang digunakan maka titik leleh cokelat semakin rendah. Hal ini dikarenakan adanya gejala eutectic, yaitu apabila dua substansi lemak berbeda dicampur maka campuran tersebut akan memadat dan mencair pada suhu yang lebih rendah dari kedua bahan pencampurnya (Misnawi, 2008), campuran lemak yang dimaksud dalam penelitian ini adalah adanya penambahan cocoa butter substitute pada setiap formulasi sebanyak $5 \%$.

Penggunaan jenis lemak nabati mempengaruhi pula terhadap titik leleh, cokelat yang memiliki rata-rata titik leleh yang rendah adalah cokelat dengan penambahan margarin, sementara cokelat yang memiliki rata-rata titik leleh yang paling tinggi adalah cokelat dengan penambahan cocoa butter dan diikuti dengan vegetable shortening. Berdasarkan hasil penelitian yang telah dilakukan, apabila ingin memperoleh produk cokelat dengan titik leleh yang baik maka dapat menggunakan formulasi pada perlakuan a1b3 (cocoa butter 15\%), a3b3 (margarin 15\%), dan a2b3 (vegetable shortening $15 \%$ ).

Goh (2002) dalam Misnawi (2008) menyatakan bahwa karakter campuran lemak dipengaruhi oleh derajat kejenuhan asam lemak penyusunnya dan panjang rantainya. Lemak dengan kandungan asam lemak jenuh yang tinggi memiliki titik cair yang lebih tinggi.

Salah satu asam lemak jenuh paling berpengaruh yang menyusun campuran lemak produk cokelat adalah stearat. Berikut adalah perbandingan kandungan asam lemak dari tiga jenis lemak nabati yang digunakan dalam penelitian.

Tabel 9. Perbandingan Komposisi Asam Lemak

\begin{tabular}{|l|l|l|l|}
\hline \multirow{2}{*}{$\begin{array}{l}\text { Asam } \\
\text { Lemak }\end{array}$} & \multicolumn{3}{|l|}{ Persentase (\%) } \\
\cline { 2 - 4 } Butter & $\begin{array}{l}\text { Vegetable } \\
\text { Shortening }\end{array}$ & Margarin \\
\hline $\begin{array}{l}\text { Asam } \\
\text { laurat }\end{array}$ & - & 0.11 & 0.31 \\
\hline $\begin{array}{l}\text { Asam } \\
\text { miristat }\end{array}$ & 0.1 & 4.46 & 2.76 \\
\hline $\begin{array}{l}\text { Asam } \\
\text { palmitat }\end{array}$ & 25.4 & 33.14 & 35.12 \\
\hline $\begin{array}{l}\text { Asam } \\
\text { palmitoleat }\end{array}$ & 0.2 & 2 & - \\
\hline $\begin{array}{l}\text { Asam } \\
\text { stearat }\end{array}$ & 33.2 & 22.98 & 13.7 \\
\hline $\begin{array}{l}\text { Asam } \\
\text { oleat }\end{array}$ & 32.6 & 31.37 & 25.4 \\
\hline $\begin{array}{l}\text { Asam } \\
\text { linoleat }\end{array}$ & 2.8 & 0.9 & 6.09 \\
\hline $\begin{array}{l}\text { Asam } \\
\text { linolenat }\end{array}$ & 0.1 & - & 0.09 \\
\hline
\end{tabular}

Sumber: O’Brien, 2003 dalam Oddang A, 2013; Manurung, 2008; Wardhani dkk, 2009.

Bentuk kristal penyusun lemak juga mempengaruhi titik leleh. Semakin stabil bentuk kristalnya, titik leleh semakin tinggi. Terkait dengan bentuk Kristal lemak maka dalam pembuatan cokelat, proses tampering mutlak harus dilakukan (Misnawi, 2008).

Tabel 10. Kristal Lemak dalam Cokelat dan Titik Lelehnya

\begin{tabular}{|l|l|l|}
\hline $\begin{array}{c}\text { No } \\
\text { Kristal }\end{array}$ & Jenis Kristal & Titik Leleh \\
\hline I & Gamma & $17^{\circ} \mathrm{C}$ \\
\hline II & Alfa & $21^{\circ} \mathrm{C}$ \\
\hline III & Beta Primer 1 & $26^{\circ} \mathrm{C}$ \\
\hline IV & Beta Primer 2 & $28^{\circ} \mathrm{C}$ \\
\hline V & Beta 2 & $34^{\circ} \mathrm{C}$ \\
\hline VI & Beta 1 & $36^{\circ} \mathrm{C}$ \\
\hline
\end{tabular}

Sumber: Syamsir, 2011.

\section{Tekstur}

Tekstur adalah karakteristik intrinsik dari suatu citra yang terkait dengan tingkat kekerasan. Tekstur adalah segi penting mutu makanan. Ciri paling penting untuk penilaian suatu makanan adalah kekerasan dan kandungan air. Tekstur kadang-kadang lebih penting daripada bau, rasa, dan warna (deMan, 1997).

Tekstur (kekerasan) dari produk cokelat merupakan interpretasi dari titik leleh campuran lemak dalam produk, penambahan dan peningkatan jumlah lemak secara langsung menurunkan kekerasan dari produk cokelat.

Berdasarkan hasil analisis tekstur (kekerasan) cokelat untuk setiap perlakuan serta hasil sidik ragam 
(ANAVA), menunjukkan bahwa interaksi antara jenis lemak nabati (A) dan jumlah lemak nabati (B) tidak berpengaruh nyata terhadap tekstur (kekerasan) cokelat. Berbeda dengan jenis lemak nabati (A) dan jumlah lemak nabati (B) yang secara mandiri memberikan pengaruh nyata terhadap tekstur (kekerasan) produk cokelat.

Tabel 11. Pengaruh Jenis Lemak Nabati (A) terhadap Tekstur Cokelat

\begin{tabular}{|l|l|l|}
\hline \multicolumn{1}{|c|}{ Jenis Lemak } & $\begin{array}{c}\text { Rata-Rata } \\
\text { (mm/10det/ } \\
\text { 100gram) }\end{array}$ & $\begin{array}{c}\text { Taraf } \\
\text { Nyata } \\
\mathbf{5 \%}\end{array}$ \\
\hline $\begin{array}{l}\text { a1 } \\
\text { (Cocoa Butter) }\end{array}$ & 0.77 & $\mathrm{a}$ \\
\hline $\begin{array}{l}\text { a2 (Vegetable } \\
\text { Shortening) }\end{array}$ & 0.87 & $\mathrm{ab}$ \\
\hline $\begin{array}{l}\text { a3 } \\
\text { (Margarin) }\end{array}$ & 0.95 & $\mathrm{~b}$ \\
\hline
\end{tabular}

Tabel 12. Pengaruh Jumlah Lemak Nabati (B) terhadap Tekstur Cokelat

\begin{tabular}{|l|l|l|}
\hline JumlahLemak & $\begin{array}{c}\text { Rata-Rata } \\
(\mathbf{m m} / \mathbf{1 0 d e t} / \\
\mathbf{1 0 0 g r a m})\end{array}$ & $\begin{array}{c}\text { Taraf } \\
\text { Nyata } \\
\mathbf{5 \%}\end{array}$ \\
\hline b1 $(25 \%)$ & 0.95 & $\mathrm{~b}$ \\
\hline b2 $(20 \%)$ & 0.85 & $\mathrm{ab}$ \\
\hline b3 $(15 \%)$ & 0.78 & $\mathrm{a}$ \\
\hline
\end{tabular}

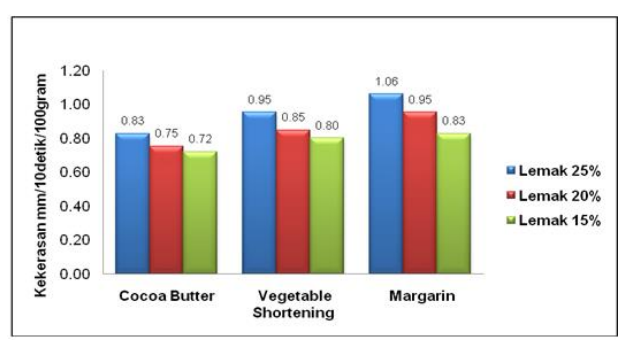

Gambar 4. Histogram Hubungan antara Jenis Lemak Nabati dan Jumlah Lemak Nabati Terhadap Tekstur Cokelat

Berdasarkan histogram diatas, menunjukkan bahwa dengan semakin meningkatnya jumlah lemak yang digunakan maka kekerasan cokelat semakin lunak (angka kekerasan semakin tinggi). Penggunaan jenis lemak nabati mempengaruhi pula terhadap kekerasan, cokelat yang memiliki kekerasan paling lunak (angka kekerasan tinggi) adalah cokelat dengan penambahan margarin, sementara cokelat yang memiliki kekerasan paling tinggi (angka kekerasan rendah) adalah cokelat dengan penambahan cocoa butter dan diikuti dengan vegetable shortening.

Sama halnya dengan titik leleh, kekerasan cokelat juga dipengaruhi oleh asam lemak penyusunnya serta karakteristik dari kristal lemak. Menurunnya kekerasan produk cokelat karena inkompabilitas lemak terjadi melalui pembentukan kisi-kisi kristal yang tidak sempurna yang dapat meningkatkan mobilitas pergerakan molekul, perubahan di dalam sturktur polimorfis serta perubahan di dalam kecepatan kristalisasi (Lanning, 1981 dan Hogenbrik, 1984 dalam Misnawi, 2008).

Tabel 13. Karakteristik Sensoris Kristal Cokelat Berdasarkan Perbedaan Titik Leleh

\begin{tabular}{|l|l|l|}
\hline $\begin{array}{c}\text { No } \\
\text { Kristal }\end{array}$ & $\begin{array}{c}\text { Suhu } \\
\text { Leleh }\end{array}$ & \multicolumn{1}{|c|}{ Efek Rasa } \\
\hline I & $17^{\circ} \mathrm{C}$ & $\begin{array}{l}\text { Lunak, mudah hancur, } \\
\text { terlalu mudah lumer }\end{array}$ \\
\hline II & $21{ }^{\circ} \mathrm{C}$ & $\begin{array}{l}\text { Lunak, mudah hancur, } \\
\text { terlalu mudah lumer }\end{array}$ \\
\hline III & $26{ }^{\circ} \mathrm{C}$ & $\begin{array}{l}\text { Padat, patah kurang } \\
\text { sempurna, terlalu } \\
\text { mudah lumer }\end{array}$ \\
\hline IV & $28^{\circ} \mathrm{C}$ & $\begin{array}{l}\text { Padat, patah kurang } \\
\text { sempurna, terlalu } \\
\text { mudah lumer }\end{array}$ \\
\hline V & $34{ }^{\circ} \mathrm{C}$ & $\begin{array}{l}\text { Mengkilap, padat, } \\
\text { renyah, leleh pada suhu } \\
\text { tubuh }\end{array}$ \\
\hline VI & $36{ }^{\circ} \mathrm{C}$ & $\begin{array}{l}\text { Keras, sulit menjadi } \\
\text { padat }\end{array}$ \\
\hline
\end{tabular}

Sumber: Sunanto, 1992.

Berdasarkan jenis kristal, kristal yang paling baik dalam menyusun produk cokelat adalah kristal beta. Kristal beta ini memiliki struktur yang kecil sehingga menghasilkan tekstur yang glossy dan mampu membentuk kelompok kristal yang besar. Untuk mendapatkan kristal yang stabil maka pembentukan kristal membutuhkan waktu yang lebih lama. Ukuran kristal yang terlalu besar akan menghasilkan produk cokelat yang tidak padat dan mudah hancur saat dipatahkan (Mulato dkk, 2002).

Berdasarkan hasil penelitian yang telah dilakukan, apabila ingin memperoleh produk cokelat dengan tekstur yang baik (keras) maka dapat menggunakan formulasi pada perlakuan a1b3 (cocoa butter 15\%), a1b2 (cocoa butter 20\%), dan a2b3 (vegetable shortening 15\%).

3) Titik Beku

Tabel 14. Pengaruh Jenis Lemak Nabati (A) terhadap Titik Beku Cokelat

\begin{tabular}{|l|l|l|}
\hline Jenis Lemak & $\begin{array}{l}\text { Rata-Rata } \\
\left({ }^{\mathbf{O} C)}\right.\end{array}$ & $\begin{array}{l}\text { Taraf } \\
\text { Nyata } \\
\mathbf{5 \%}\end{array}$ \\
\hline $\begin{array}{l}\text { a1 } \\
\text { (Cocoa Butter) }\end{array}$ & 25.39 & $\mathrm{~b}$ \\
\hline $\begin{array}{l}\text { a2 } \\
\text { (Vegetable } \\
\text { Shortening) }\end{array}$ & 24.67 & $\mathrm{~b}$ \\
\hline $\begin{array}{l}\text { a3 } \\
\text { (Margarin) }\end{array}$ & 23.39 & $\mathrm{a}$ \\
\hline
\end{tabular}

Berdasarkan hasil analisis titik beku cokelat untuk setiap perlakuan serta hasil sidik ragam (ANAVA), menunjukkan bahwa jumlah lemak nabati (B) secara mandiri tidak memberikan pengaruh nyata 
terhadap titik beku produk cokelat, sama halnya dengan interaksi antara jenis lemak nabati (A) dan jumlah lemak nabati (B) tidak berpengaruh nyata terhadap titik beku cokelat. Berbeda dengan jenis lemak nabati (A) yang secara mandiri memberikan pengaruh nyata terhadap titik beku produk cokelat.

Semakin panjang rantai asam lemak penyusunnya, semakin tinggi titik lelehnya (Goh, 2002 dalam Misnawi, 2008) serta semakin mudah membeku dan semakin sukar larut lemak tersebut.

Asam-asam lemak sebagai komponen penyusun lemak dalam bahan baku (cocoa butter, vegetable shortening, dan margarin) memiliki rantai asam lemak yang berbeda-beda sehingga akan berdampak pada titik beku dari masing-masing produk cokelat.

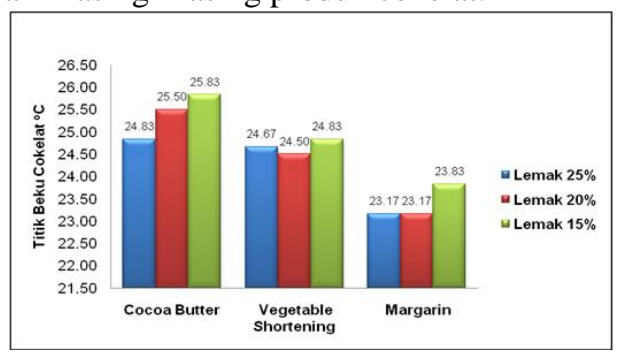

Gambar 5. Histogram Hubungan antara Jenis Lemak Nabati dan Jumlah Lemak Nabati Terhadap Titik Beku Cokelat

Berdasarkan histogram diatas, menunjukkan bahwa dengan semakin meningkatnya jumlah lemak yang digunakan maka titik beku cokelat semakin rendah. Penggunaan jenis lemak nabati mempengaruhi pula terhadap titik beku, cokelat yang memiliki titik beku paling rendah adalah cokelat dengan penambahan margarin, sementara cokelat yang memiliki titik beku paling tinggi adalah cokelat dengan penambahan cocoa butter dan diikuti dengan vegetable shortening.

Produk cokelat dengan jumlah lemak yang paling kecil $\left(b_{3}\right)$ di semua jenis lemak yang digunakan memiliki titik beku lebih tinggi dibandingkan dengan kedua jumlah lemak lainnya $\left(b_{2}\right.$ dan $\left.b_{1}\right)$, hal ini dikarenakan kecepatan membeku dari produk cokelat dengan jumlah lemak lebih kecil $\left(b_{3}\right)$ akan lebih cepat dibandingkan dengan produk cokelat dengan jumlah lemak yang besar $\left(b_{2}\right.$ dan $\left.b_{1}\right)$ sehingga pada suhu yang lebih tinggi produk cokelat $\left(b_{1}\right)$ telah membeku. Semakin banyak lemak yang digunakan dalam formulasi maka titik beku semakin rendah.

Berdasarkan hasil penelitian yang telah dilakukan, apabila ingin memperoleh produk cokelat dengan titik beku yang tinggi (beku di suhu ruang) maka dapat menggunakan formulasi pada perlakuan a1b3 (cocoa butter 15\%), a1b2 (cocoa butter 20\%), dan a2b3 (vegetable shortening $15 \%$ ).

\section{Uji Organoleptik}

a. Rasa

Rasa merupakan faktor yang yang penting dari suatu produk makanan, tekstur dan konsistensi suatu bahan makanan akan mempengaruhi cita rasa yang ditimbahkan oleh bahan tersebut. Rasa dipengaruhi oleh beberapa faktor yaitu senyawa kimia, suhu, konsentrasi dan interaksi komponen rasa lainnya. (Winarno, 1991).

Penilaian terhadap cita rasa menunjukan penerimaan konsumen terhadap suatu bahan makanan. Penilaian terhadap citarasa pada umumnya dilakukan dengan menggunakan alat indra pengecap manusia yaitu lidah (Winarno, 1991).

Berdasarkan data hasil perhitungan ANAVA Lampiran 10.A, menunjukkan bahwa jenis lemak nabati (A) berpengaruh nyata terhadap rasa produk cokelat, sedangkan jumlah lemak nabati (B) dan interaksi antara jenis lemak nabati (A) dan jumlah lemak nabati (B) tidak berpengaruh nyata terhadap rasa dari produk cokelat.

Tabel 15. Pengaruh Jenis Lemak Nabati (A) terhadap Rasa Cokelat

\begin{tabular}{|l|l|l|}
\hline \multicolumn{1}{|c|}{ Jenis Lemak } & Rata-Rata & \multicolumn{1}{|c|}{$\begin{array}{c}\text { Taraf } \\
\text { Nyata } \\
\mathbf{5 \%}\end{array}$} \\
\hline $\begin{array}{l}\text { a1 (Cocoa } \\
\text { Butter) }\end{array}$ & 4.52 & $\mathrm{~b}$ \\
\hline $\begin{array}{l}\text { a2 (Vegetable } \\
\text { Shortening) }\end{array}$ & 4.29 & $\mathrm{ab}$ \\
\hline a3 (Margarin) & 2.17 & $\mathrm{a}$ \\
\hline
\end{tabular}

Pada Tabel 15 diketahui bahwa penggunaan cocoa butter (a1) sebagai sumber lemak menunjukan perbedaan yang signifikan dengan penggunaan margarin (a3) terhadap rasa dari produk cokelat, akan tetapi tidak menunjukan perbedaan yang signifikan dengan penggunaan vegetable shortening (a2) terhadap rasa produk cokelat.

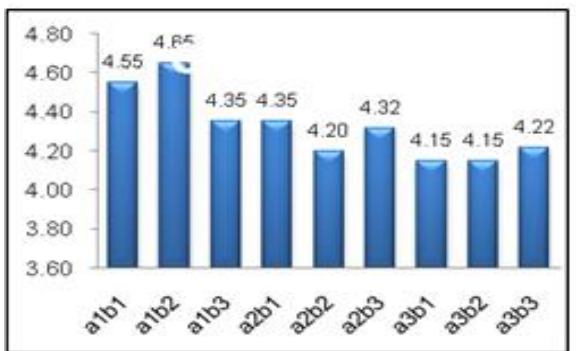

Gambar 6. Histogram Hubungan antara Jenis Lemak Nabati dan Jumlah Lemak Nabati Terhadap Rasa Cokelat

Rasa merupakan faktor yang cukup penting dari suatu produk makanan selain warna dan aroma, komponen yang dapat menimbulkan rasa diinginkan tergantung dari senyawa penyusunnya. Misalnya bumbu-bumbu dan bahan tambahan lainnya yang sengaja ditambahkan yang dapat memberikan rasa yang khas pada beberapa produk makanan (Saleh, 2005).

Rasa dominan yang timbul dari produk cokelat adalah rasa cokelat yang khas, rasa cokelat yang khas pada produk paling disukai adalah produk dengan 
sumber lemak cocoa butter dan vegetable shortening, hal ini dikarenakan cocoa butter memeliki rasa khas cokelat yang khas sehingga menjadikan produk akhir memiliki rasa khas cokelat yang lebih kuat, kemudian rasa dasar dari vegetable shortening adalah plain sehingga tidak mengganggu rasa dari produk akhir cokelat dan penerimaan panelis terhadap produk cokelat. Produk cokelat yang menggunakan vegetable shortening tidak memiliki perbedaan yang signifikan dengan produk cokelat yang menggunakan cocoa butter. Sementara itu produk cokelat dengan penggunaan margarin sebagai sumber lemak memiliki rasa yang kurang baik, hal ini karena margarin memiliki rasa khas tersendiri disebabkan komponen pangan lain seperti zat pewarna (karoten), vitamin, air, pengawet, dan emulsifier untuk menstabilkan emulsi yang terbentuk (Ketaren, 1986).

Untuk menghasilkan rasa yang lebih baik selain penambahan dari bahan-bahan yang digunakan juga diperlukan statu proses pencampuran yang baik, dimana pada proses pencampuran tersebut meliputi proses pemanasan dan proses penghancuran, pada pembuatan produk cokelat proses pencampuran ini disebut proses conching (Saleh, 2005).

Berdasarkan hasil penelitian yang telah dilakukan, apabila ingin memperoleh produk cokelat dengan rasa yang baik (keras) maka dapat menggunakan formulasi pada perlakuan a1b2 (cocoa butter 20\%), a1b1 (cocoa butter 25\%), dan a2b1 (vegetable shortening 25\%).

\section{b. Tekstur (Mouthfeel)}

Setiap bahan pangan memiliki tekstur yang bermacam-macam. Hal ini tergantung kepada bahan baku, bahan penujang yang digunakan serta proses produksi yang dilakukan (Kartika, B., Hastuti, P, Supartono, W,. 1987).

Parameter tekstur dibagi menjadi dua bagian, yaitu finger feel dan mouth feel. Mouth feel adalah kesan kinestetik pengunyahan makanan dalam mulut yang mencakup kelompok kesan yang dinyatakan dengan istilah chewiness, fibrousness, grittiness, mealiness, stickness, dan oiliness. Penilaian tekstur suatu bahan di mulut mulai dapat dirasakan ketika bahan dipotong, dikunyah, dan ditelan (Kramer, 1966)

Tekstur (mouthfeel) yang dijadikan parameter adalah tekstur berpasir dan sifat waxy pada langit-langit mulut ketika produk dikonsumsi. Tingkat kehalusan merupakan salah satu parameter yang menentukan karakteristik dari cokelat yang dihasilkan. Tingkat kehalusan cokelat dipengaruhi oleh formulasi dan waktu conching. Penggunaan waktu conching yang relatif singkat akan menyebabkan bahan-bahan yang digunakan dalam pembuatan produk cokelat belum tercampur dengan sempurna sehingga akan menimbulkan tekstur yang tidak stabil (Saleh, 2005). Tingkat kehalusan yang yang rendah akan memberikan efek smoothness pada cokelat. Jika tingkat kehalusan cokelat tinggi maka akan terasa gritty. Menurut Minifie (1989), ukuran partikel cokelat yang paling baik adalah partikel dengan ukuran 30-40 mikron.

Berdasarkan data hasil perhitungan ANAVA Lampiran 10.B, menunjukkan bahwa jenis lemak nabati (A), jumlah lemak nabati (B), dan interaksi antara jenis lemak nabati (A) dan jumlah lemak nabati (B) tidak berpengaruh nyata terhadap tekstur (mouth feel) dari produk cokelat.

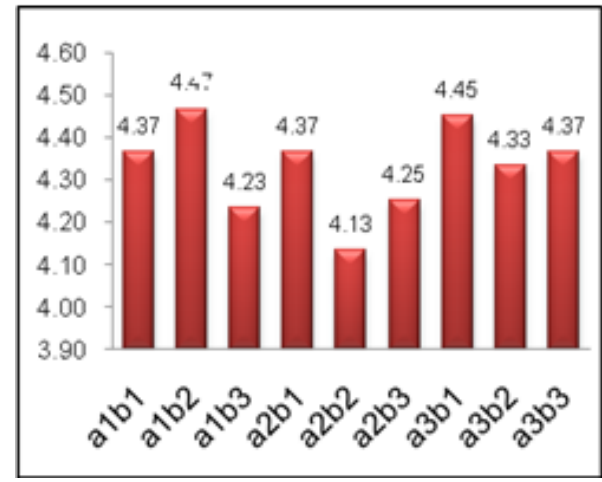

Gambar 7. Histogram Hubungan antara Jenis Lemak Nabati dan Jumlah Lemak Nabati Terhadap Tekstur Cokelat

Penerimaan panelis terhadap produk cokelat seluruh formulasi tidak memiliki perbedaan yang signifikan, hal ini dikarenakan tekstur berpasir produk cokelat tidak dipengaruhi oleh jenis dan jumlah lemak nabati. Meskipun sifat waxy pada bahan baku lemak (cocoa butter, vegetable shortening, margarin) berbedabeda namun setelah menjadi produk perbedaannya tidak signifikan sehingga tingkat penerimaan panelis terhadap produk tidak jauh berbeda.

Cokelat harus dapat meleleh dalam mulut, yakni ketika dimakan tanpa perlu meninggalkan kesan keras. Tekstur seperti lilin (waxy mouth feel) menandakan bahwa cokelat mengandung sejumlah lemak. Cokelat merupakan dispersi partikel - partikel dari bubuk cokelat dan gula di dalam suatu fase cair lemak kakao. Pada suhu kamar partikel - partikel tersebut disekat oleh kristal-kristal lemak yang bertindak sebagai semen perekat. Oleh karena itu sifat-sifat fisik dan sensori cokelat langsung berhubungan dengan kristalisasi lemak kakao (Prasetya, 2009).

Berdasarkan hasil penelitian yang telah dilakukan, apabila ingin memperoleh produk cokelat dengan tekstur (mouthfeel) yang lembut dan lebih disukai konsumen maka dapat menggunakan formulasi pada perlakuan a1b2 (cocoa butter 20\%), a3b1 (margarin 25\%), dan a3b3 (margarin 15\%).

\section{c. Aroma}

Aroma suatu bahan pangan merupakan fungsi dari kandungan bahan yang dimilikinya. Aroma bahan pangan dapat menentukan kelezatan suatu bahan pangan. Dalam hal ini aroma dipengaruhi oleh alat panca indera pencium (hidung). Pada umumnya aroma yang diterima oleh hidung dan otak lebih banyak 
merupakan campuran dari empat aroma yaitu harum, asam, tengik dan hangus (Winarno, 1991).

Berdasarkan data hasil perhitungan ANAVA 10.C, menunjukkan bahwa jenis lemak nabati (A) berpengaruh nyata terhadap aroma produk cokelat, sedangkan jumlah lemak nabati (B) dan interaksi antara jenis lemak nabati dan jumlah lemak nabati (B) tidak berpengaruh nyata terhadap aroma dari produk cokelat.

Tabel 16. Pengaruh Jenis Lemak Nabati (A) terhadap Aroma Cokelat

\begin{tabular}{|l|l|l|}
\hline \multicolumn{1}{|c|}{ Jenis Lemak } & Rata-Rata & $\begin{array}{c}\text { Taraf } \\
\text { Nyata } \\
\mathbf{5 \%}\end{array}$ \\
\hline a1 (Cocoa Butter) & 4.46 & $\mathrm{~b}$ \\
\hline $\begin{array}{l}\text { a2 (Vegetable } \\
\text { Shortening) }\end{array}$ & 4.16 & $\mathrm{ab}$ \\
\hline a3 (Margarin) & 4.06 & $\mathrm{a}$ \\
\hline
\end{tabular}

Berdasarkan Tabel 16 diatas, ditunjukan bahwa pada perlakuan a1 tidak berbeda nyata dengan perlakuan a2, namun memiliki perbedaan yang signifikan dengan perlakuan a3. Hal ini dikarenakan setiap jenis lemak nabati yang digunakan dalam penelitian ini memiliki aroma yang berbeda-beda, sehingga berdampak berbeda pula terhadap aroma dari produk akhir cokelat. Cocoa butter memiliki aroma khas coklat yang cukup kuat, vegetable shortening tidak beraroma (plain) sementara margarin memiliki aroma khas tersendiri.

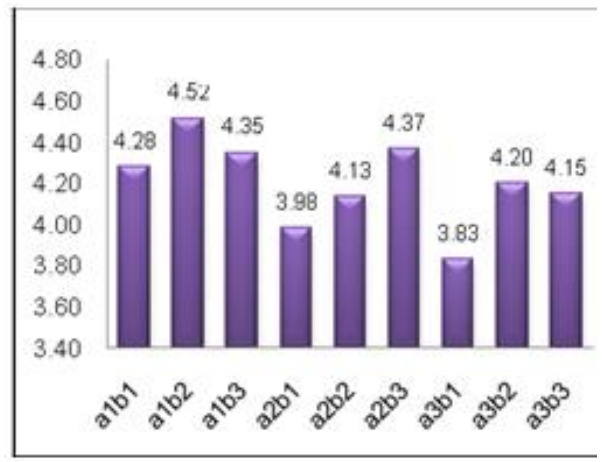

Gambar 8. Histogram Hubungan antara Jenis Lemak Nabati dan Jumlah Lemak Nabati Terhadap Aroma Cokelat

Berdasarkan hasil penelitian yang telah dilakukan, apabila ingin memperoleh produk cokelat dengan aroma cokelat yang khas dan lebih disukai konsumen maka dapat menggunakan formulasi pada perlakuan a1b2 (cocoa butter 20\%), a2b3 (vegetable shortening 15\%), dan a1b3 (cocoa butter 15\%).

Aroma yang timbul pada produk cokelat batang dapat disebabkan dari proses conching. Dimana dari proses conching inilah ditujukan untuk meningkatkan aroma khas cokelat dan juga dapat menghilangkan baubau yang tidak dikehendaki. Penyebab timbulnya aroma dari proses conching, dapat disebabkan karena penambahan zat-zat penambah cita rasa dan aroma, seperti cocoa powder dengan penambahan gula akan lebih meningkatkan aroma khas cokelat (Widiantara, 2004).

Proses conching yang dilakukan pada pembuatan cokelat menggunakan suhu yang cukup tinggi yaitu $60^{\circ} \mathrm{C}$ dan dengan waktu 8 jam mengakibatkan cokelat dengan penambahan margarin sebagai sumber lemak mejadi beraroma kurang baik. Hal ini karena margarin merupakan lemak nabati yang dihasilkan melalui proses pencampuran antara minyak kelapa, minyak, sawit, stearin, dan bahan tambahan lainnya (Setiawan, 2002). Adanya komponen minyak dalam margarin mengakibatkan terjadinya perubahan aroma selama proses pengolahan khususnya conching. Pada lemak dan minyak dikenal dua tipe kerusakan utama yaitu ketengikan dan hidrolisis. Ketengikan terjadi bila komponen cita rasa dan bau mudah menguap terbentuk sebagai akibat kerusakan oksidatif dari lemak dan minyak yang tak jenuh. Komponen-komponen ini menyebabkan bau dan cita rasa yang tidak diinginkan dalam lemak dan minyak dan produk-produk mengandung lemak dan minyak (Raharjo, S, 2004 dalam Wardhani 2009).

\section{d. After Taste (Pahit)}

Berdasarkan data hasil perhitungan ANAVA 10.D, menunjukkan bahwa jenis lemak nabati (A) tidak berpengaruh nyata terhadap after taste produk cokelat, begitu pula dengan jumlah lemak nabati (B) dan interaksi antara jenis lemak nabati dan jumlah lemak nabati (B) yang tidak berpengaruh nyata terhadap after taste dari produk cokelat.

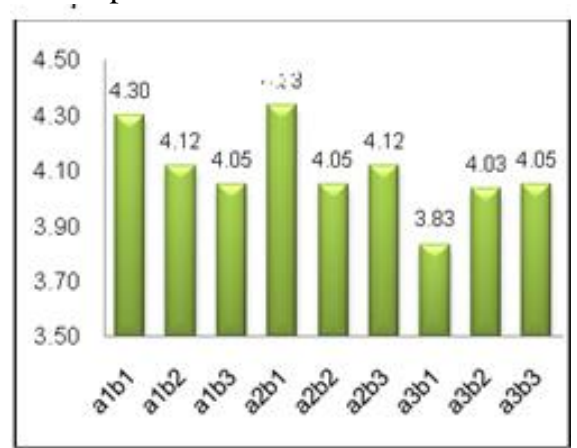

Gambar 9. Histogram Hubungan antara Jenis Lemak Nabati dan Jumlah Lemak Nabati Terhadap After Taste Cokelat

After tase dari dark chocolate yang lebih dominan adalah rasa pahit karena bahan baku yang digunakan adalah cocoa powder. Rasa pahit adalah cita rasa khas alami yang terasa dari dalam cokelat. Rasa tersebut berasal dari komponen-komponen alkaloid seperti theobromine, kafein, komponen fenolik, pyrazine beberapa peptida dan asam amino bebas. Rasa pahit cokelat seringkali rancu dengan rasa sepat karena orang tidak sepenuhnya mengerti sifat dan perbedaan antara kedua rasa tersebut, terlebih lagi tanin dan polifenol dalam cokelat sebegai komponen yang paling bertanggung jawab terhadap rasa sepat dan juga rasa pahit (Armita, 2009) 
After taste pahit cokelat dengan formulasi b3 (15\%) tidak begitu disukai panelis, hal ini karena pada formulasi jumlah lemak b3 (15\%) penambahan cocoa powder sebanyak $40 \%$ sehingga after taste dari produk cokelat lebih pahit dari dua formulasi lainnya yaitu b1 (25\%) dan b2 (20\%). Apabila ingin memperoleh produk cokelat dengan after taste pahit yang disukai konsumen maka dapat menggunakan formulasi pada perlakuan $\mathrm{a} 2 \mathrm{~b} 1$ (vegetable shortening 25\%), a1b1 (cocoa butter $25 \%$ ), dan a $2 \mathrm{~b} 3$ (vegetable shortening 15\%).

Berdasarkan hasil penelitian, dapat diambil kesimpulan sebagai berikut :

1. Berdasarkan penelitian pendahuluan dengan uji organoleptik, perlakuan jumlah lemak terpilih dari penelitian pendahuluan I (cocoa butter) adalah $25 \%$, penelitian pendahuluan II (vegetable shortening) adalah $20 \%$, dan penelitian pendahuluan III (margarin) adalah $15 \%$.

2. Berdasarkan penelitian utama, jenis lemak nabati (A) memberikan pengaruh nyata terhadap karakteristik produk meliputi respon kimia (kadar lemak), repon fisika (titik leleh, tekstur dan titik beku), respon organoleptik (rasa dan aroma). Jumlah lemak nabati (B) memberikan pengaruh nyata terhadap karakteristik produk meliputi respon kimia (kadar lemak), respon fisika (titik leleh dan tekstur). Interaksi antara jenis lemak nabati (A) dan jumlah lemak nabati (B) memberikan pengaruh nyata terhadap respon fisika (titik leleh).

\section{Daftar Pustaka}

1. Armita. 2009. Tentang Cokelat. https://4rmita.wordpress.com/category/tentangcokelat/page/6/. Diakses: 26 Juni 2016.

2. Astawan, M. 2009. Sehat dengan Hidangan Kacang dan Biji-Bijian. Niaga Swadaya, Jakarta.

3. Fakhmi, M. 2016. Perbedaan Lama dan Suhu Tampering Terhadap Karakteristik Cokelat Filling Selai Kacang. Tugas Akhir. UNPAS, Bandung.

4. Gaspersz, V. 1990. Metode Perancangan Percobaan. Armico, Bandung.

5. Kartika, B., Hastuti, P,. Supartono, W,. 1987. Pedoman Uji Inderawi Bahan Pangan. PAU Pangan dan Gizi, Universitas Gajah Mada, Yogyakarata.

6. Ketaren, S. 1986. Minyak dan Lemak Pangan. Penerbit: Universitas Indonesia.

7. Khomsan, A. 2004. Peranan Pangan dan Gizi untuk Kualitas Hidup. PT Gramedia Widia Sarana Indonesia, Jakarta.

8. Kramer, A dan Twigg, B. S. 1966. Fundamental Of Quality Control The Food Industry. The AVI Publishing Company Inc.

9. Manurung, H. 2008. Pengaruh Suhu dan Lama Pengadukan pada Proses Kristalisasi dalam Pembuatan Pastry Shortening dari Fraksinasi
Minyak Kelapa Sawit. Jurnal Penelitian, Universitas HKBP, Medan.

10. Minifie, W. Beinard, 1989. Chocolate, Cocoa, and Confectionery SainsTechnology. An Aspen Publication, London.

11. Misnawi. 2008. Karakteristik Campuran Lemak Kakao dan Stearin Dalam Sistem Cokelat Susu. Pusat Penelitian Kopi dan Kakao Indonesia, Jember.

12. Moeljianingsih. 2011. Pengaruh Penambahan Lesitin Terhadap Kualitas Permen Cokelat Selama Penyimpanan Suhu Kamar.

13. Muchtadi, D. 1989. Petunjuk Laboratorium Evaluasi Nilai Gizi Pangan. Institut Pertanian Bogor, Bogor.

14. Mulato, S., Widyotomo, S., Handaka., (2002), Desain teknologi pengolahan pasta, lemak, dan bubuk cokelat untuk kelompok tani, http://pustaka.bogor.net/w261041.pdf. Diakses: 27 Juni 2016.

15. Oddang, A. A. 2013. Analisis Kadar Asam Lemak Trans dalam Gorengan dan Miyak Bekas Hasil Penggorengan Makanan Jajanan di Lingkungan Whorkshop Universitas Hasanuddin Makasar. Jurnal Penelitian, Universirtas Hasanuddin, Makasar.

16. Pusat data Sistem Informasi Pertanian. 2014. Outlook Komoditi Kakao. Kementrian Pertanian.

17. Saleh, I. 2005. Pengaruh Penambahan Inulin (Chicorium Intybus) Dan Waktu Conching Terhadap Karakteristik Produk Cokelat. Tugas Akhir, Universitas Pasundan Bandung.

18. Setiawan, E. 2002. Sifat Fisik, Kimia, dan Organoleptik Margarin Manis dengan Penambahan Aspartam. Skripsi, Institut Pertanian Bogor.

19. Siregar, T. H. S., Slamet. R., Laeli, N. 2000. Budidaya, Pengolahan dan Pemasaran Cokelat. Penerbit: PT. Penebar Swadaya, Jakarta.

20. Syamsir, E. 2011. Mengenal Proses Pembuatan Cokelat. http://ilmupangan.blogspot.co.id. Diakses: 1 Maret 2016.

21. Wardhani, P, dkk. 2009. Analisis Tingkat Kerusakan Lemak Nabati dan Lemak Hewani Akibat Proses Pemanasan. Jurnal Penelitian, UIN Syarif Hidayatullah, Jakarta.

22. Widiantara, T. 2004. Peningkatan Karakteristik Produk Cokelat Olahan Dengan Fortifikasi Inulin dan Soy Powder. Tesis.UNPAS, Bandung.

23. Winarno, F. G. 1991. Kimia Pangan dan Gizi. Penerbit: PT Gramedia Pstaka Utama, Jakarta.

24. Zogina, N. M. B. 2015. Perbandingan Antara Soy Powder Dengan Susu Bubuk Dan Konsentrasi Grean Tea Terhadap Karakteristik Dark Chocolate. Tugas Akhir, Universitas Pasundan, Bandung. 